\title{
Implementation of Government Collaboration Policy and Citizen Toward Coronavirus: A Literature Review
}

\author{
Sukmawati ${ }^{1}$, Rijal ${ }^{2}$, Musdalifah $\mathrm{Haz}^{3}$ \\ ${ }^{1}$ Universitas Muhammadiyah Makassar, Makassar, Indonesia \\ ${ }^{2,3}$ Institut Ilmu Sosial dan Ilmu Politik (IISIP) Yapis Biak, Papua, Indonesia \\ Email: sukmawati22031997@ gmail.com
}

(Received: January-2021; Reviewed: February-2021; Accepted: March-2021;

Avalaible Online: March-2021; Published: March-2021)

(c) (5) This is an open access article distributed under the Creative Commons Attribution License EY NG CC-BY-NC-4.0 (2021 by author (https://creativecommons.org/licenses/by-nc/4.0/)

\begin{abstract}
Coronavirus is stated to have almost spread throughout the world. Indonesia became one of the countries exposed to the coronavirus. Therefore, Indonesia has made policies in dealing with coronavirus. One of these policies is the collaboration between the government and Palopo citizens in dealing with the coronavirus. This study aims to determine the implementation collaboration policy between the government and Palopo citizens in dealing with the coronavirus. This study employed literature research. Literature research is research used in collecting information and data with the help of various materials in the library such as documents, books, magazines, historical stories, and news. The sources in this study are based on the object studied and based on sources affiliated with the research. In this study, data collection was obtained from news and articles in online journals. This study showed that the implementation of collaboration policy between the government and Palopo citizens measured the communication, resources, disposition, and bureaucratic structure. These are considered a lack of implementation.
\end{abstract}

Keywords: Policy; government; government collaboration policy; coronavirus.

\section{INTRODUCTION}

At the beginning of 2020, the world was shocked by the spread of a new type of coronavirus (SARS-CoV-2) and a disease called Corona Virus Disease 2019 (Covid-19) (Annas et al., 2020; Djalante et al., 2020; Rasjid et al., 2021; Rosyidi et al., 2021; Sukendro et al., 2020; Windarwati et al., 2020). As reported, the origin of the virus originated in Wuhan, Tongkook, which was discovered in late December 2019. Until now, it has been confirmed that there are in 200 countries that have been diseased; one of them is in Indonesia. WHO has also declared the coronavirus as a pandemic which means that coronavirus has spread to almost all the world and the entire world population is likely to be infected from this virus (Annas et al., 2020; 
Djalante et al., 2020; Rasjid et al., 2021; Rosyidi et al., 2021; Sukendro et al., 2020; Windarwati et al., 2020).

Coronavirus has infected 30 million people and made a big impact on the world. Countries around the world began implementing lockdown and continued to use masks to prevent the spread of coronavirus (Ardiputra et al., 2020). A coronavirus is a group of viruses from the subfamily Orthocronavirinae in Coronaviridae and the Order of Nidovirales. This group of viruses can cause disease in birds and mammals, including humans. In humans, coronavirus generally causes mild respiratory infections, such as colds, and the most common symptoms at the time were fever, dry cough, and fatigue. However, it is known that each person has a different coronavirus response.

In the current condition, Corona Virus is not an outbreak that can be ignored. When viewed from the symptoms, the layman will think it is only limited to ordinary influenza, but the virus is quite dangerous and deadly for medical analysis. The coronavirus in Indonesia today has an impact on the entire community. According to Kompas, on March 28, 2020, the impact of the Covid-19 virus occurred in various fields such as social, economic, tourism and education. Circular Letter (SE) issued by the government on March 18, 2020, stated that all indoor and outdoor activities in all sectors were temporarily postponed to reduce coronavirus spread.

Furthermore, in a press statement at the Presidential Palace Bogor, West Java, Tuesday, March 31, 2020, President Jokowi set a policy of Large-Scale Social Restrictions (PSBB) and the status of public health emergencies. In the current crisis, all sorts of political decisions will have side effects. Therefore, to reduce these side effects, the decision requires a major component in the formulation and decision making, namely the collaboration conducted by the government and the public in overcoming the coronavirus. In this case, public resilience in trusting government institutions is at stake. The various appeals issued will not have an effective impact if there is no community resilience to follow it together. To be able to encourage that, the government must be open and firm in its implementation.

In this pandemic, many goods and services were found a surge in prices in line with the surge in public demand. Some products have decreased, and there are even products that were found a surge in demand. Some traders use this pandemic to see the market opportunities, one of which is the high market demand for mask products and hand sanitizer. People prioritize their spending to buy products that are useful for self-protection, not to be exposed to Corona Virus. As presented by Kotler (2008, p. 345), price (price) is the sum of all the value given by the customer to benefit from owning or using a product or service. Swastha and Iriawan (2003, p. 36) also provide the view that the price is an exchange rate for the benefits of goods or services. So the higher the consumer feels the benefits of the product, the higher the exchange rate of an item. The high level of sales of masks and hand-sanitizer at this time is one of the impacts of the Corona Virus.

One of the government's collaborations with the community is where companies in suppressing the pace of movement of these workers become important. Adisasmita (2010, p. 232) stated that "collaboration is related to the arrangement of clear cooperation, trust balanced with commitment, structure and institutional capacity". The government must expressly give signs to entrepreneurs regarding what steps to take in the face of the Corona Virus. Without a firm from the state, the handling of the coronavirus spread in each company will only depend on the initiative of the entrepreneur. In addition, collaboration with the private sector is also necessary to multiply the coronavirus spread test, as emphasized by the Director-General of WHO. To deal with the pandemic, more tests are needed to find out who has been infected. 
A collaboration between the Palopo city government and community must also be implemented where Palopo city government should always urge the community always to keep their distance and wear masks when going out of the house when doing activities.

Although the spread of coronavirus occurs very quickly, most Palopo citizens still consider this a normal thing and not something to worry about. People think that this is a virus that is only similar to influenza, which most people with such thoughts become the initial belief and many who underestimate coronavirus. Whereas what is seen until now, this virus has taken many fatalities. This happens because of the mindset of the Palopo citizens that is inappropriate. Community mindset related to maintaining health and minimal medicine is also one of the causes.

Therefore, the importance of addressing the spread of coronavirus is expected that the Palopo citizens are always ready to comply with the regulations set by the Palopo city Government that must build multiparty collaboration with Neighbourhood/ Community Association, noncommissioned law enforcement officer, Community/NGO/ Independent Institutions, Companies/Business World, Regional House of Representatives and Local Hous of Representative, Private Hospital and IT Covid-19 volunteer.

Therefore, the government and the public must continue to heed and prevent the coronavirus from increasing and soon disappear in 2021. But until now, some communities have not set the existing regulations. There are still many people who do activities outside the home but do not follow the health protocol. They do not realize that the purpose of regulatory regulation is to be avoided and exposed to the coronavirus. The lack of government resources of Palopo city and facilities as well as infrastructure is still inadequate to be one of the problems that hinder collaboration between the Government and Palopo citizens. Thus, the government should be able to balance their respective roles to achieve the objectives of the government and community collaboration program in addressing the spread of the coronavirus in Palopo city and surrounding areas.

\section{METHOD}

This study employed literature research. The data were collected from various materials in the library, such as documents, books, magazines, historical stories, and news. According to the literature research experts, literature research is theoretical studies, references, and other scientific literature related to culture, values, and norms developed in the social situation (Sugiyono, 2012). The resources in this study are based on the object studied and affiliation related to the research. In this study, data collection was obtained from news and articles in online journals. Researchers searched articles using the keywords "coronavirus" and "policy implementation."

While data analysis techniques using models of Miles et al. (2014) in qualitative data analysis, there is four flow of activities that occur simultaneously. Activities in data analysis are Data Collection, Data Condensation, Data Display, and Conclusion Drawing/Verifications.

\section{RESULT AND DISCUSSION}

Implementation of policies in the handling of coronavirus is a policy of collaboration between the government and the Palopo citizens during the pandemic in addressing the spread of coronavirus. The coronavirus pandemic is making life; individual behavior, community response; business and economic governance, state governance, and global relations are undergoing visible changes. Changes that take place and lead to the new normal is the implication of the regulation during the coronavirus emergency response period such as 
lockdown and isolation at the community level, social distancing, work from home mechanisms, distance learning, efficiency, and refocusing of resources, as well as other adjustments that later become new capacity.

The results of this study contribute to the implementation of government and community collaboration policy in dealing with coronavirus in Palopo city, which uses the Theory of Edward III (Agustino, 2016). Edward III's theory established four dimensions that are interconnected with each other, namely: communication, resources, disposition, and bureaucratic structure.

\section{Communication}

Communication in Palopo city area has been coordinating thoroughly well with Neighbourhood/Community Association, noncommissioned law enforcement officer, Community/NGO/ Independent Institutions, Companies/ Business World, Regional House of Representatives and Local Hous of Representative, Private Hospital and IT Covid-19 volunteer. All these stakeholders are collaborated in dealing with coronavirus. The response from the informant given the question by the researchers suggested that during the coronavirus period, the government always provide instruction to organize the existing health protocol. But some people also are not aware, so it becomes an obstacle to implementing policies. According to Indiahono (2009, p. 31), policies will be implemented properly if there is effective communication between the implementers of the policy program and the target groups, namely the community.

There was information among the public that if the people who do the swab test and the result are positive, then handling the cost of the test will be borne by the state. But if the swab test result is negative, then the cost burden must be borne by yourself. Also, people exposed to Corona Virus will be more because people who undergo a swab bag and are declared negative but have to pay for themselves will automatically look for free even if their name is listed in positive terms to avoid spending much money.

Therefore, in this pandemic, communication and information sharing to the public is a priority to make the public more confident that coronavirus exists and endanger everyone's lives. It can also reduce the spread of coronavirus with a sense of public trust in existing protocols.

The objectives of policy can be well socialized to avoid distortions in policies and programs made. This is certainly important for the target group of the policy because the higher the knowledge of the target group on the program made it will reduce the level of rejection and error in applying for the policy program in the face of the coronavirus.

From the above statement, it can be seen that there must be a balance between government communication as a policy implementer and the community as a target group. Also, there needs to be more effective communication because if the government and the Palopo citizens already know the objectives and objectives of the collaboration policy, then the implementation of the policy will run to the maximum in addressing the spread of coronavirus.

\section{Human Resources}

The resources in the implementation of collaboration policies of the government and the Palopo citizens still need a team of volunteers who are well aware of the coronavirus, as well as facilities in Palopo city in the prevention of coronavirus is still very inadequate, such as when some people are infected with coronavirus must be isolated in Makassar city. Hence, it is not easy to assess the implementation of collaboration policy programs. So, the Palopo city 
government must also cooperate with companies or outside parties to conduct collaboration training activities to address the spread of coronavirus in the Palopo city area.

Tahir (2015, p. 66) suggests that resource factors have an important role in the implementation of policy, because however clear and consistent a provision or rules of an obligation, if the person responsible for implementing the policy does not have the resources to do the work effectively, then the implementation of the policy will not be able to run optimally and effectively. From the above statement, it can be known that the number of resources is important in the implementation of the policy, a balanced workload in the number of personnel will make the performance run effectively (Farida et al., 2015; Langkai et al., 2019; Niswaty et al., 2019; Smith \& Akib, 2015; Syamsiar et al., 2018).

It is known that resources are divided into two, namely financial resources and human resources. Financial resources are a crucial factor considering the coronavirus pandemic requires very expensive costs to manage, such as the fulfillment of facilities and medical devices and public facilities to prevent coronavirus spread. In addition, the widespread impact of this pandemic resulted in a decline in some sectors of life, such as the economic sector. Many people lost their livelihoods due to the pandemic, so that the welfare of the community is also a big responsibility of the government.

Human resources are also very influential in this policy; experts are needed, such as doctors and health workers who take care of patients, policymakers, and spokespeople to communicate this policy well to the public.

\section{Disposition}

The commitment and responsibility regarding the government and community collaboration policy program are going quite well. Where if the Implementor has a good disposition, it will certainly be able to run the policy well as what is cooled by policymakers, then the implementation process also becomes effective, it can also be stated that the government is ready to collaborate in preventing the spread of coronavirus with the community in Palopo city area. This is indicated by the enthusiasm of the Palopo City Government, who always directs the community to always adhere to applicable health protocols such as using masks and hand-sanitizer when doing activities outside the home. The attitude of the government, in this case, is a very important factor in the implementation of the policy. The government in taking the policy has the desire just to implement it and must have the desire to implement the policy.

Nevertheless, from the above research can still be assessed that not all people can collaborate with the government because of distrust of the dangerous Corona Virus. Therefore, Palopo citizens should continue to be given education about prevention and handling related to coronavirus. Educating the community in Palopo City Area is certainly not easy, but it does not mean it can not be done. It takes certain insights, strategies, and methods to approach the community. Challenges in the field such as dealing with the attitude of rejection or stubbornness of some people in Palopo city area. This is understandable because maybe some people already feel bored for months of being at home alone.

Therefore, the government must be more professional in educating the community, because professionalism is closely related to commitment and honesty in carrying out a job. This will affect the course of policy, because the important character possessed by implementors is honesty, commitment and democracy. according to Edward III in Indiahono (2009), the important character possessed by implementors is honesty, commitment, and democracy. Implementors who have a high commitment and honest will always survive the obstacles encountered in the program or policy making. 


\section{Bureaucratic Structure}

From the results found by the researchers, the researchers interpreted that the program or policy collaboration of the Government and Community in the Palopo city area is in accordance with the regulations set by the Central Government and has been given the responsibility to implement the policy program. The organizational structure in charge of implementing policies against one of the important structural aspects of each personalization is standard operating procedures. In addition to standard operational procedures, the dissemination of responsibility is also a factor that can boost the performance of bureaucratic structures in a better direction. The bureaucratic structure also greatly influences the implementation of policy. A clear bureaucratic structure will provide a clear chain of command so that there is no mistake in the performance of the policy because it follows a single unity of orders. A clear bureaucratic structure will also provide clarity of responsibility to each implementing unit so that there is no overlap of tasks, the role of the organization will be effective and efficient

From the researchers' observations above, it can be seen that the Palopo City Government has a clear duty and responsibility in making a policy program collaboration with the community in the face of coronavirus. The policy will go well, as Edward III said in Agustino (Agustino, 2016), which suggests that with the fragmented bureaucratic structure that aims to spread the responsibility of various activities, activities, or programs in several work units under their respective fields, the implementation will be effective and maximal because competent and capable organizations carry it out.

\section{Inhibiting and Supporting Factors}

From the results of the study obtained in the above research, the map of inhibitory problems are:

1. Lack of public trust related to coronavirus so ignore every health protocol that exists, which makes the collaboration policy of government and society experiencing obstacles

2. There is still a lack of facilities owned by the Palopo city government in overcoming coronavirus and patients who are affected by coronavirus because the public does not get education from the beginning related to the danger of Corona Virus.

3. As society considers that coronavirus is only a harmless virus, so many people ultimately do not heed the policies made by the Palopo City Government.

While the supporting factors are:

1. The existence of Circular Letter (SE) issued by the government on March 18, 2020, where it is said that all indoor and outdoor activities in all sectors are temporarily postponed in order to reduce the spread of coronavirus, and this is the reference for Palopo city government in implementing government and community collaboration policy in addressing the spread of coronavirus.

2. There is support from outside parties involved and related companies that support and adequately facilitate policy activities to implement the Policy Program collaboration of the Government and Local Communities of Palopo City in the Face of Corona Virus.

3. The existence of good communication between policy makers and policy makers and the objectives of the policy. 


\section{CONCLUSION}

The implementation of the policy of collaboration between government and Palopo citizen is based on Edward III Theory that measures four dimensions: communication, resources, disposition, and bureaucratic structure. There was a deficiency or not optimal in the implementation of each dimension. Communication was found still a lack of clear information related to coronavirus given to the community. Some Palopo citizens ignored using masks and hand-sanitizer when interacting outside the house. This study also found that there was a lack of facilities provided by the government of Palopo city in tackling the coronavirus. The number of patients in Palopo is low, so they were sent to Makassar. As for disposition found some people consider that the policy made by the government only for its benefit to make the community is not involved in the collaboration created by the Palopo government. In contrast, with the cooperation, public trust with the government will guarantee the spread of coronavirus will run well. For the bureaucratic structure, it was found that the Palopo city government is ready to make a policy of collaboration with the community because the activity is a responsibility and a given task and can be optimal in implementing.

\section{REFERENCES}

Adisasmita, R. (2010). Pembangunan Pedesaan dan Perkotaan. Yogyakarta: Graha Ilmu. Agustino, L. (2016). Dasar-Dasar Kebijakan Publik. Bandung: Alfabeta.

Annas, S., Isbar Pratama, M., Rifandi, M., Sanusi, W., \& Side, S. (2020). Stability analysis and numerical simulation of SEIR model for pandemic COVID-19 spread in Indonesia. Chaos, $\begin{array}{lllll}\text { Solitons } \quad \& \quad \text { Fractals, } & 139, & 110072 .\end{array}$ https://doi.org/https://doi.org/10.1016/j.chaos.2020.110072

Ardiputra, S., Prawira Rizky, M., Tasbir, M., Permata Utama, S., Listiawati, N., \& Qadrini, L. (2020). Pembagian Masker dan Sosialisasi Kebijakan Pemerintah Dalam Rangka Mendukung Pencegahan Penyebaran Covid-19 Pada Masyarakat Desa Pallis Kecamatan Balanipa. Communnity Development Journal, 1(3), 395-400.

Djalante, R., Lassa, J., Setiamarga, D., Sudjatma, A., Indrawan, M., Haryanto, B., Mahfud, C., Sinapoy, M. S., Djalante, S., Rafliana, I., Gunawan, L. A., Surtiari, G. A. K., \& Warsilah, H. (2020). Review and analysis of current responses to COVID-19 in Indonesia: Period of January to March 2020. Progress in Disaster Science, 6, 100091. https://doi.org/https://doi.org/10.1016/j.pdisas.2020.100091

Farida, U., Akib, H., \& Jasruddin. (2015). Policy implementation of the national program for community empowerment in rural areas healthy and intelligent generation in Mamuju regency of West Sulawesi, Indonesia. International Journal of Economic Research, 12(5).

Indiahono, D. (2009). Kebijakan Publik Berbasis Dynamic Policy Analysis. Yogyakarta: Gava Media.

Kotler, P. (2008). Manajemen Pemasaran Edisi 12 Jilid 2. Jakarta: Indeks.

Langkai, J. E., Akib, H., \& Sendouw, R. H. E. (2019). The determinants of neighborhood based development policy implementation in Manado city. International Journal of Recent Technology and Engineering, $8(2$ Special Issue 9). https://doi.org/10.35940/ijrte.B1047.0982S919

Miles, M. ., Heburman, A. ., \& Saldana, J. (2014). Qualitative Data Analysis, A Methods Sourcebook (Edition 3). USA : Sage Publications. Terjemahan Tjetjep Rohindi Rohidi, UIPress.

Niswaty, R., Juniati, F., Darwis, M., Salam, R., \& Arhas, S. H. (2019). The Effectiveness of Leadership Functions Implementation in The Makassar Departement of Manpower. JPBM 
(Jurnal Pendidikan Bisnis Dan Manajemen), 5(1), 1-10.

Rasjid, Z. E., Setiawan, R., \& Effendi, A. (2021). A Comparison: Prediction of Death and Infected COVID-19 Cases in Indonesia Using Time Series Smoothing and LSTM Neural Network. Procedia Computer Science, 179, 982-988. https://doi.org/https://doi.org/10.1016/j.procs.2021.01.102

Rosyidi, R. M., Wisnu Wardhana, D. P., Apriawan, T., Al Fauzi, A., Priyanto, B., Gunawan, K., Nugroho, S. W., Prihastomo, K. T., Nasution, M. D., \& Ihwan, A. (2021). Algorithm of traumatic brain injury management at Indonesia in the COVID 19 pandemic ERA. Retrospective cohort study. Annals of Medicine and Surgery, 62, 98-103. https://doi.org/https://doi.org/10.1016/j.amsu.2021.01.008

Smith, A., \& Akib, H. (2015). The Implementation Effectiveness of Trash Management in Ambon, Maluku: The Influence of Socialization, Coordination and Control to the Effectiveness of Trash Management. International Journal of Public Administration, 38(10). https://doi.org/10.1080/01900692.2014.908214

Sugiyono. (2012). Metode Penelitian Kuantitatif, Kualitatif, Dan R\&D. Bandung: Alfabeta.

Sukendro, S., Habibi, A., Khaeruddin, K., Indrayana, B., Syahruddin, S., Makadada, F. A., \& Hakim, H. (2020). Using an extended Technology Acceptance Model to understand students' use of e-learning during Covid-19: Indonesian sport science education context. Heliyon, 6(11), e05410. https://doi.org/https://doi.org/10.1016/j.heliyon.2020.e05410

Swastha, B., \& Iriawan. (2003). Manajemen Pemasaran Modern (Edisi Kedu). Yogyakarta: Liberty Offset.

Syamsiar, S., Saggaf, M. S., Salam, R., \& Ihsan, S. R. (2018). Implementation Of Supervision On Office Of Community Empowerment And Makassar City Village. THE INTERNATIONAL CONFERENCE ON SOCIAL SCIENCES AND HUMANITIES 2018.

Tahir, A. (2015). Kebijakan Publik \& Transparansi Penyelenggaraan Pemerintah Daerah. Bandung: Alfabeta.

Windarwati, H. D., Oktaviana, W., Mukarromah, I., Ati, N. A. L., Rizzal, A. F., \& Sulaksono, A. D. (2020). In the middle of the COVID-19 outbreak: Early practical guidelines for psychosocial aspects of COVID-19 in East Java, Indonesia. Psychiatry Research, 293, 113395. https://doi.org/https://doi.org/10.1016/j.psychres.2020.113395 